\title{
進行大腸癌に対する骨盤内臓器全摘術症例の検討
}

\author{
国立霞ヶ浦病院外科 \\ 菅野 康吉 影山 隆久 遠山 隆夫 \\ 稲垣 宏 田村洋一郎 斉藤 英夫
EXPERIENCE OF TOTAL PELVIC EXENTERATION FOR ADVANCED COLORECTAL CARCINOMA \\ Kokichi SUGANO, Takahisa KAGEYAMA, Takao TOYAMA
Hiroshi INAGAKI, Youichirou TAMURA and Hideo SAITOU
}

Department of Surgery, National Kasumigaura Hospital

\begin{abstract}
骨盤内臓器全摘術を施行した進行大腸癌 8 例について検討を加えた。過大な手術侵襲に対する対策 としてSwan-Ganz カテーテルによる術後管理が有効であった. 血行動態の変化は出血量 $3,000 \mathrm{ml}$ 以 上の症例では著明であったが，一方高齢者であっても適切な術後管理を行完ば安全に手術が施行可能 と考光られた。強度の资症あるいは膿瘍を合併する例では肉眼所見から浸潤範囲，リンパ節転移の有 無などの正確な判定は困難であった，死亡 3 例はいずれも局所再発によるものであり平均生存期間は 12 力で, 内訳は広範な他喴器浸潤, 腹膜転移陽性例, リンパ節転陽性例, 未分化癌症例などであっ た.
\end{abstract}

索引用語：進行大腸癌, 骨盤内臟器全摘術, Swan-Ganz カテーテル

I.はじめに

骨盤内他臓器浸潤を伴う進行直腸, S 状結腸癌に対 して外科的治㾍切除を行うために種々の藏器の合併切 除が必要となる。女性症例では子宮, 臸などの生殖器 の合併切除のみで十分な治瘾が得られる場合が多く, 手術侵襲も比較的軽度であるが, 男性症例では膀胱, 精囊, 前立腺などの泌尿生殖器系臟器への浸潤が多く, このような例では浸潤藏器の部分切除のみでは治瘦切 除が困難であることが少なくない，近年骨盤内臓器全 摘術が広範な骨盤内浸潤例に対して施行される術式と なりつつあるが，手術侵襲が大きく，尿路の再建が必 要であること, 術後の長期予後に関してもいまだ不明 の点が多いこと, 患者に与党る肉体的, 精神的苦痛の 大きさなどの理由により広く一般化した術式とはなっ ていない.

われわれは1982年より現在までに 8 例の進行直腸, $\mathrm{S}$ 状結腸癌に対して骨盤内葴器全摘術を経験し, 若干

$<1986$ 年 7 月 9 日受理 $>$ 別刷請求先：菅野 康吉 ₹160 新宿区信濃町 35 慶応義塾大学医学部外科
の知見を得たので検討を加え報告する．

\section{II. 対象症例}

対象は1982年 1 月より1984年 2 月までの 2 年間に国 立霞ヶ浦病院外科に怙いて骨盤内藏器全摘術（total pelvic exenteration, 以下 TPE と略す）を施行した直 腸癌 6 例, $\mathrm{S}$ 状結腸癌 1 例, 直腸 $\mathrm{S}$ 状結腸重複癌 1 例 の計 8 例である。な拉リンパ節転移，組織学的壁深達 度, 進行程度分類などの表現はすべて大腸癌取り扱い 規約に基づいて行っだ1.

\section{III. 結 果}

1. 年齢拉よび性

年龄は30歳から74歳にわたり, 平均54.6歳であった。 性別は男性 7 例, 女性 1 例であった（表 1 ）。

2. 手術術式

全例に手術前日 Swan-Ganz カテーテルを挿入し， 術中お゙よび術後の循環動態のモニタリングを行ってい る.

全麻下にて碎石位で開腹し，腹腔内を検索し腫汮の 骨盤内臓器への漫潤が著しく通常の腹会陰式直腸切断 術では切除不能であり, かつ明らかな肝転移, 腹膜播 
表 1 骨盤内藏器全摘術施行例

\begin{tabular}{|c|c|c|c|c|c|}
\hline 五 & 年 $\mathrm{s}$ & 性 別 & 部 位 & 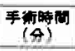 & 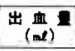 \\
\hline 1 & 50 & 男 & Rs & 545 & 5200 \\
\hline 2 & 74 & 女 & RsRa & 695 & 4000 \\
\hline 3 & 72 & 男 & Rs & 420 & 800 \\
\hline 4 & 35 & 男 & $\mathbf{R b}$ & 310 & 1800 \\
\hline 5 & 69 & 男 & S, Rb & 410 & 3400 \\
\hline 6 & 30 & 男 & Ra & 475 & 3700 \\
\hline 7 & 44 & 男 & $R \mathbf{b}$ & 380 & 1900 \\
\hline 8 & 63 & 男 & s & 393 & 1250 \\
\hline
\end{tabular}

種が無いことを確認して手術を開始する．下腸間膜動 脈を根部にて結禁切断し，下腸間膜動脈起始部より郭 清を開始し，そこから下方に向い大動脈前面より両側 の内外腸骨動脈領域のリンパ節の郭清を行う。両側の 内腸骨動脈は上殿動脈分岐部より末梢側で結禁切断し ている．仙骨前面を十分に剥離して後方の切離を終え たのち，骨盤側壁腹膜を切開し膀脱の前面に入り前方 の切離を開始するが, 腫瘍の骨盤腔内への浸潤が強く, 巨大な腫瘤を形成しているような場合にはこの上らな 定型的手技が困難であり，実際には後方々前方の切離 を交互に繰り返し，また会陰側からの切離を同時に加 えて, 腹腔側および会陰側の両方向から切除を進めて ゆく場合が少なくない。

摘出後了後, 閉鎤孔周囲の郭清をさらに追加し, 生 食 $5,000 \mathrm{ml}$ を腹腔側より注入し骨盤腔内を洗浄した 後, 会陰側より仙骨前面にドレーンを拽入し, 会陰創 を 1 層で閉鎖する.

尿路の再建は全例回腸導管により行って抢り，尿管 全層と回腸粘膜を 4-0クローミックカットグートに て端側吻合し, 補強のため浆膜桨膜縫合を加兄, 右下 腹部にストーマを造設している。

人工肛門は通常の腹会陰式直腸切断術之同様に腹膜 外法で左下腹部に造設した。

骨盤底の再建は 1 例で大網を用いて行っているが, 他の 7 例では施行していない.

3. 手術時間, 術中出血量, 術後循環動態

手術時間は最高695分, 平均454分, 術中出血量は最 高 $5,200 \mathrm{ml}$, 平均 $2,756 \mathrm{ml}$ であった(表 1 ). 過大な手術 侵襲に対する対策としてわれわれは全例に SwanGanz カテーテルを挿入し, 術後の循環動態の管理を 行っている(図 1). 術前と術後を比較すると左室 1 回 拍出仕事量指数 (left ventricular systolic work index 以下 LVSWI と略す) は全例で低下し，全末梢血管抵 抗指数 (systemic vascular resistance 以下 SVR と略 寸) は 8 例中 6 例で増加, 心指数 (cardiac index 以下
表 2 病理組織学的検討

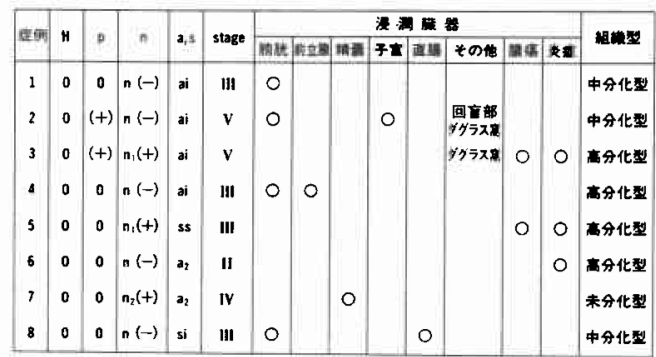

図 1 骨盤内藏器全摘術術後血行動態

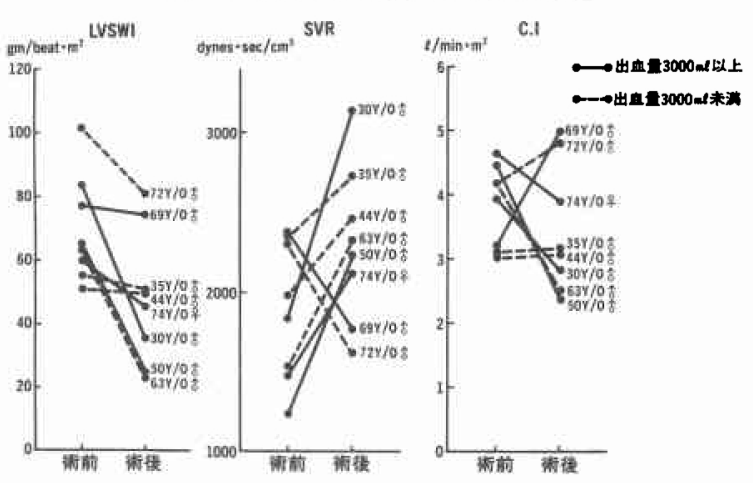

$\mathrm{CI}$ と略す)は 8 例中 5 例で低下した。さらにグラフ実 線で示すよらに出血量 $3,000 \mathrm{ml}$ 以上の症例では LVSWI は全例で低下, SVR は 4 例中 3 例で増加, CI は 4 例中 3 例で低下を示し, hypovolemia に基づく血 行動態の変化が著名であった。また年齢による比較で は高齢であってる出血量が少なければ血行動態に及ぼ す影響は比較的少ないものと考えられた。

\section{4. 病理組織学的検討}

病理組織学的検討では症例 2,3 に秥いて術中明ら かな腹膜播種の無いことを確認したにもかかわらず $\mathrm{p}$ （十）と診断されている（表 2)。これらはいずれもダ グラス窩への直接浸潤を伴い広範な他蔵器浸潤，ある いは炎症，膿湯を合併し，一塊となって腫瘤を形成し た例で臨床的には腹膜転移が播種によるるのか，浸潤 によるるのかを判定するのは困難であった、リンパ節 転移陽性例は 8 例中 3 例に認められ，1群リンパ節転 移陽性例 2 例, 2 群リンパ節転移陽性例 1 例であった。 組織学的壁深達度でみると他蔵器浸潤例 (si, ai) は 8 例中 5 例であった。浸潤臓器は膀胱が 8 例中 4 例と最 も多く, 以下前立腺, 子宮, 直腸, 回盲部が各 1 例で あった。をた膀胖に浸潤の認められなかった 4 例中， 
表 3 リンパ節転移：肉眼所見と組織学的所見の比較

\begin{tabular}{|c|c|c|c|c|c|}
\hline & $n(-)$ & $n_{1}(t)$ & $n_{2}(t)$ & $n_{3}(+)$ & At \\
\hline $\mathbf{N}(-)$ & 2 & 1 & & & 3 \\
\hline$N_{1}(+)$ & 2 & 1 & & & 1 \\
\hline $\mathrm{N}_{2}(+)$ & & & 1 & & 1 \\
\hline $\mathbf{N}_{3}(+)$ & 1 & & & & 1 \\
\hline it & 5 & 2 & 1 & 0 & \\
\hline
\end{tabular}

表 4 術後合併症

\begin{tabular}{|c|c|}
\hline 具孟睪次 & 3 例 \\
\hline 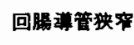 & 1 \\
\hline 水骨症 & 1 例 \\
\hline 尿 & 1 例 \\
\hline 下肢浮期 & 10 \\
\hline 刢感染 & 1 \\
\hline イレ & \\
\hline
\end{tabular}

2 例で病変部と膀胱壁の間に炎症を伴う膿瘍形成が認 められ，3例に強い炎症が認められた。病理組織型は 未分化癌 1 例, 中分化腺癌 3 例, 高分化腺癌 4 例で, 進行程度は stage II 1 例, stage III 4 例, stage IV 1 例, stage V 2 例であった。

リンパ節転移の肉眼的所見と組織学的所見の比較を 示す(表 3 ). 組織学的診断では 5 例がリンパ節転移陰 性（n(一)）であったのに対し，術中の肉眼的所見で リンパ節転移陰性（N(一)）と判断されたものは 3 例 であり，肉眼的所見と組織学的所見が一致し，リンパ 節転移を正確に判定し党たものは 8 例中 4 例に過ぎな かった。誤診例 4 例の中には资症合併例 3 例のらち 2 例が含まれており，炎症によるリンパ節の反応性腫大 はリンパ節転移との鑑別が困難であった。

5. 術後合併症

術後合併症は腎孟腎炎が 3 例と最む多く, 以下回腸 導管狭窄，水腎症，尿瘻，下肢浮腫，創感染，イレウ ス各 1 例となり，尿路再建に起因するるのが比較的多 数を占めている，再手術を要したるのはイレウスの 1 例のみであった（表 4 ）。

6. 術後経過および転帰

手術施行後の経過年数は最長 2 年 4 カ月であり, 予 後について検討すると手術直接死亡は 1 例もなく， 3 例が術後11力月, 13 力月, 12 力 月で再発死亡している. ·再発死亡例の術後平均生存期間は12力月であった（図 2 ).

7. 再発死亡例の検討

死亡例は全例局所再発によるすのであった（表 5 ）.
図 2 骨盤内臟器全摘術施行例の予後

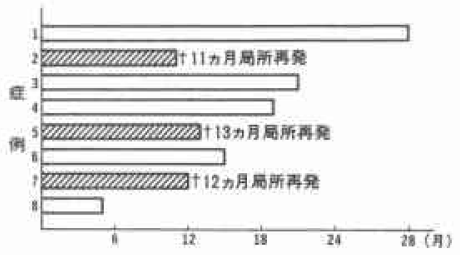

表 5 再発死亡例の検討

\begin{tabular}{|c|c|c|c|c|c|c|c|c|c|c|c|}
\hline 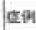 & 74 & Hin & 趾位 & H & $p$ & n & a.s & 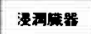 & 相粰型 & F基裂式 & 生存期夙 \\
\hline 2 & 74 & 女 & Rs Re & 0 & $(+)$ & $h(-)$ & al & 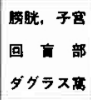 & 中分化型 & 為 并 & 11 月 \\
\hline 5 & 69 & 男 & Rb & 0 & 0 & $n(t)$ & ss & 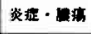 & 要分化型 & 用 所 & 13 カ月 \\
\hline$?$ & 44 & 男 & Rb & 0 & 0 & $n_{1}(t)$ & $a_{2}$ & 梢童 & 未分化型 & 属 所 & 12力月 \\
\hline
\end{tabular}

症例 2 は開腹時ダグラス窩と回盲部への浸潤を認め, 初回手術で人工肛門造設のみに終ったが, その後血尿 が増悪し，再手術を施行， TPE と回盲部合併切除を 行った症例である。

症例 5 は直腸・S 状結腸重複癌で主病巣はS 状結腸 にあり, 直腸に Borrmann 1 型の随伴病変が認められ た. 主病巣の組織学的壁深達度はssであったが，膀胼 との間に炎症と膿瘍形成を認め，1群りンパ節転移陽 性であった。

症例 7 は壁深達度 $a_{2}$ であったが 2 群リンパ節転移 を認め，組織型は未分化癌であった。

\section{IV. 考 察}

TPEは1948年 Brunschwigにより進行子宮癌に対 する治㞠法として発表された術式であり2)，その後欧 米では膀胱癌, 大腸癌などの骨盤内腫晹の治療として

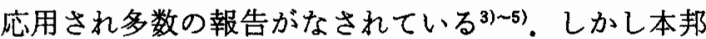
に怙いては進行下部大腸癌に対する TPEの報告は比 較的少なく1113)15〉，ことに一般病院において標準術式 として積極的にこれを採用している施設は少ないもの と考觉られる。

このように TPEが最近まで一般的に行われる術式 となりえなかった理由として手術侵意の大きさが举げ られる。排便，排尿および性機能の廃絶が患者に与え る肉体的精神的苦痛は外科医にとって本術式の施行を 敬遠させる大さな原因となっており，また大腸癌に対 する一般的認識も欧米に比べて比較的低く患者の理解 を得るのが困難であったといら社会的背景も無視でき ないものであった. しかしながら近年食生活の欧米化 
にともない大腸癌は増加傾向にあり, 従来の外科的治 療の成績が明らかになるにつれてさらに生存率の向上 を目指した拡大手術の必要性が認められ，一方悪性腫 瘍の増加に伴い癌の手術に対する患者側の理解も以前 より得やすい状況になってきていることる当院におい てTPEを導入するようになった大きな要因である。

また手術死亡の多いことも比較的最近まで本術式の 普及を妨げた理由であると思われる。 Brunschwigの 報告では1960年ごろまで手術死亡率は $20 \%$ 前後と高 (2)6), 比較的最近の報告です $10 \%$ 前後とするものが多 ( ${ }^{577) 8)}$. 死因としては肺梗塞, 成人呼吸促迫症候群など の肺合併症, 敗血症, 心不全などが挙げられている8 本邦では小山らの報告では23例中 2 例 $(8.7 \%)^{13)}$, 森ら の報告でも14例中 1 例 $(7.14 \%)^{15)}$ ， 欧米に比へてて手 術死亡は比較的少なく，われわれの症例でも手術死亡 は 1 例も無かった。このように手術死亡が低い理由と して, 第 1 に比較的最近に施行された例が多く, 30年 以上の経験を持つ欧米に比へてて, 術中, 術後に適切な 管理が行われるようになったこと，第 2 に人種的特性 として欧米の報告で術死の原因として多く報告される 肺梗塞などの肺合併症が少ないことが挙げられる。ま た Boey らの報告では65歳以上の高龄者では手術死亡 率は $33.3 \%$ と, 65歳未満症例の $9.7 \%$ に比べて有意に高 く, 高龄者で poor risk となる可能性が指摘されてい るが9), われわれの経験では高龄者であっても SwanGanz カテーテルでモニタリングした循環動態の変化 は著明なるのではなく, むしろ出血量 $3,000 \mathrm{ml}$ 以上の 症例で変化が著しかった。 このことはたと京龄者で あっても出血量を少なくし，適切な術後管理を行兄ば 絶対的な禁忌とはなり兄ず，十分安全に手術を施行し らることを示唆しているものと思われる. Orr らは 31 例の骨盤内臓器摘出術施行例にたいし Swan-Ganz カ テーテルを使用し prospective studyを行い心肺合併 症の発生を 1 例も認めなかった ${ }^{10)}$ 。を Girtanner ら は術後 ICU での集中的管理, 機械的補助呼吸, SwanGanz カテーテルの使用, 塞栓予防のためのへパリン 投与, 下大静脈のプリケーションなどの方法により手 術死亡率を $27 \%$ から $6.7 \%$ に低下させえたと報告して 扣り ${ }^{8)}$, 術後管理の重要性を強調している.

摘出標本を病理組織学的に検討した結果, 他臓器浸 潤の程度とリンパ節転移の診断が術中の肉眼的所見と 一致しない場合があることが明らかとなった。すなわ ち術後の病理組織検查で膀胼への浸潤を認めなかった 4 例中 3 例で膀胼壁との間に強度の炎症むるい:膿湟
の形成を認め, 術中肉眼的所見による壁深達度の診断 が困難であった。これらの炎症, 膿瘍合併例では結果 的にみると TPEを行わなくても治癒切除が可能であ り oversurgeryではなかったかという反省が生じる。 いずれの場合にも通常の腹会陰式直腸切断術では切除 不能であるといら判断のもとに手術が施行されており やむをえない症例であったと考えられるが，術前，術 中の診断で炎症の合併, 浸潤の範囲をさらに正確に判 定するよう診断技術の向上をはかる必要があうう。し かし，かりに炎症の合併が術前に診断されたとしても 他藏器浸潤が絶対に無いことを証明することは現時点 では極めて困難である．大見らは下部直腸癌の局所再 発例と非局所再発例について検討し，局所再発例では ew が有意に短く, ew $1 \mathrm{~mm}$ 以下の症例では 5 例中 4 例 $(80 \%)$ に局所再発が見られたと述べている。また 壁深達度 $\mathrm{a}_{2}$ 以上の症例では局所再発にたいする ew の安全限界は $6 \mathrm{~mm}$ 以上であり, 直腸前壁の癌で $\mathrm{a}_{2}$ と 考光られるものにたいしては積極的に広範かつ十分な 他藏器合併切除が根治を得るために必要であると述べ ている12).

同様にリンパ節転移に関しても術中多数のリンパ節 腫大を認めたにも関わらず組織学的には転移陰性の場 合があり，特に炎症合併例で顕著であった，高木らは 12 例中 5 例に炎症合併を認め, リンパ節転移陽性例は 5 例中 1 例のみであったとし, 術中下腸間膜リンパ節 （No. 253）の生検を行い転移のないことを確認してか ら適応を決定していると述べている11. われわれの検 討でもリンパ節転移陽性の 3 例中 2 例が再発死亡して おり，少なくとも第 3 群以上のリンパ節転移の無いこ とを明らかにして手術適応を決定する必要があるすの と思われる。

術後合併症についての検討では尿路变更に起因する むのが 6 例と比較的多数を占めている，水腎症の 1 例 は腎不全となり外来にて血液透析を施行中であるが, 他の 5 例はいずれる保存的治療にて軽快した。下肢の 浮腫を生じた例は当初広範な郭清により生じた下肢の リンパ流の循環障害によるものと考えていたが, 術後 次第に増悪し12力月目に局所再発により死亡してお り, 合併症というょりはむしろ再発の徵候を示すもの と考光られる。

合併症の内で再手術が必要となったものはイレウス の 1 例のみであった。術後早期の癒着性イレウスにつ いて小山らは TPE 23例中 3 例を経験し，いずれも痗 着剥離術のみで軽快したと述べているが13)，われわれ 
の経験した例は骨盤底に小腸が陥入し㾤着したために 生じたもので 1 回目の再手術で癒着剥離術を試みたが 再度イレゥスとなり，2回目の再手術でバイバスを行 い漸く治撚せしめた。

Lifshitz らは58例の骨盤内臟器摘出術施行例につい て検討を加え，骨盤底の再建を行っていない26例では 4 例に小腸イレウスが生じたのに対し，大網を用いて 骨盤底を再建した 32 例では術後早期のイレウスは 1 例 も認められなかったと述べている14). われわれの経験 した例では骨盤底の再建は行っておらず，このような 合併症予防のために骨盤底の再建をするべきであるの か今後の検討を要する点と思われる。

最後に本術式の手術適応と, あわせて再発死亡例に ついての検討を述べる. 小山らは TPEの手術適応と $し て ， 1 ）$ 直腸・S 状結腸癌が膀胼, 前立腺, 尿道など に浸潤している臨床的な徴候があること,2）浸潤が部 分的な切除では不十分と考充られるほど広範囲に及心゙ か, または解剖学的には局所切除可能でむ, 術後の機 能障害が著しく排尿機能の回復が困難と考之られる場 合, 3）局所的に完全切除が不可能なことを示唆する徵 候 (下肢の浮腫, 坐骨神経痛, 尿道の骨盤入口部での 閉塞など)がない，などを挙げている 適応を広げて,1）根治手術可能な尿路系と大腸への広 範囲漫潤を伴う場合, 2) 根治手術不能でも人工肛門と 尿路系の再建を必要とし, かつ局所切除可能な場合 (例, N4 (+)例, 術後照射可能な局所遺残例, 他部位 の転移のない中等度肝転移例など)などを挙げて招り， たと充治㾤切除が不可能であっても患者の愁訴を解消 できる可能性があれば reduction surgeryとしての TPEを施行し, 術後免疫化学療法の併用により寛解を 維持するといら積極的な意見を述べている ${ }^{15}$. われわ れの経験した再発死亡例 3 例のらち, 症例 2 は広範な 骨盤外への他荿器浸潤と腹膜転移を認めた症例であ り, 初回手術時に切除不能と考えられていたが，血尿 が増悪したために行った非治癒切除例である。術後 11 カ月目に再発死亡しているが，短期間とはい方社会復 州が可能となり，患者の苦痛も軽減できたことを考え ると, 手術の意義は多少なりともあったものと思われ る. 症例 5 は治瘾切除例と考穴られたが, 術後 13 月 目に局所再発により死亡している。剖検も許されな かったため確定はできないが，死亡直前の諸検查では 明らかな遠隔転移の徵候は認めていない.リンパ節転 移陽性であったことが局所再発の要因であるとも考壳 られる。症例 7 子術後 12 力月目に局所再発死亡してい
るが，この症例は術直後より両下肢に進行性の浮腫を 生じたもので, 組織型が未分化癌であったこと拉よび 2 群リンパ節転移陽性であり，腫場の骨盤内組織への 漫潤が予想以上のものであり非治澺切除に終わってい る可能性があろ5.

以上の再発死亡例 3 例についてその特徽を一言で述 べるならば， 1 例は非治癒切除例， 1 例は治空切除で はあるがリンパ節転移陽性例，そして残りの1例は非 治痹切除に近いと考えられる症例である。前揭の小山 らの報告でも根治手術15例のらちリンパ節転移陰性例 5 例中 4 例が生存しているのに対して, リンパ節転移 陽性例10例中生存は 1 例のみであり, 特に側方リンパ 節転移陽性例では予後不良である ${ }^{13)}$. 自験例からの印 象を述べるならば，リンパ節転移の有無はTPEの予 後を左右する重要な要素であり，良好な予後を期待で きるのは局所的に発達し強度の炎症を合併し畽瘤形成 性が強いが，脈管侵襲が比較的軽微でリンバ節転移の 無い発育形式をとる腫湢と考号られる。したがって各 死亡例を 1 例ずつ見てゆくとそれぞれに再発してる不 思議では無いと考党られる根拠が見出され，小山らの 挙げる手術適応についてる良好な予後を期待するら兄 で十分考慮すべきものと思われる，そのらえでたとえ 非治㾤切除となってもあえて施行するだけのメリット があるかどらかを加味して症例の選択を行うべきであ ろら.

以上，いまだ日も浅く，症例数も8例と少ないため 末知の点も多いが，文献と対比しながら当院で行った 骨盤内臓器全摘術施行例について検討を加えた。

\section{V. まとめ}

骨盤内藏器全摘術を施行した 8 例について検討を加 え報告した。

（1）出血量 $3,000 \mathrm{ml}$ 以上の症例では血行動態の変化 は大きく，術後管理にSwan-Ganzカテーテルが有用 であった。

（2） 8 例中 3 例に炎症をたは膿瘍の合併を認め，こ れらの症例ではリンパ節転移, 浸潤部位の肉眼的判定 は困難な場合が多い，

（3）術後合併症は尿路感染, 回腸導管狭窄, 水腎症, 尿瘻など尿路再建に関するものが比較的多く認められ たが腎不全となり透析を要した 1 例を除き保存的治療 にて軽快した。

（4）手術直接死亡は 1 例もなく，8例中 3 例が再発 死亡している. 再発死亡例の術後平均生存期間は 12 力 月であり, 死因は全例局所再発によるものであった。 
（5）再発死亡例の予後不良となった要因として広範 な骨盤外他缄器浸潤例, 腹膜転移陽性例, リンパ節転 移陽性例，末分化癌症例などが考えられた。

本論文の要旨は第 24 回日本消化器外科学会総会 (昭和59 年 7 月京都）に拈いて発表した.

\section{文献}

1）大腸癌研究会編：臨床・病理大腸癌取扱い規約. 改 訂第 3 版，東京，金原出版，1983

2) Brunschwig A: Complete excision of pelvic viscera for advanced carcinoma. A one-stage abdominoperineal operation with end colostomy and bilateral ureteral implantation into the colon above the colostomy. Cancer 1 : 177-183, 1948

3) Brunschwig A: Pelvic exenteration for carcinoma of the lower colon. Surgery 40 : 691-695, 1956

4) Butcher HR, Spjut GJ: An evaluation of pelvic exenteration for advanced carcinoma of the lower colon. Cancer 12:681-687, 1959

5) Ledesma EJ, Bruno S, Mittelman A: Total pelvic exenteration in colorectal disease a 20 . year experience. Ann Surg $194: 701-703,1981$

6) Brunschwig A, Daniel W: Pelvic exenteration operation with summary of sixty-six cases surviving more than five years. Ann Surg 151 : $571-576,1960$

7) Eckhauser FE, Lindenauer SM, Worley GW :
Pelvic exenteration for advanced rectal carcinoma. Am J Surg 138 : 411-414, 1979

8) Girtanner R, Campo $T$, Alleyn J et al: Routine intensive care for pelvic exenterative operations. Surg Gynecol Obstet 153 : 657-659, 1981

9) Boey J, Wong J, Ong GB : Pelvic exenteration for locally advanced colorectal cancer. Ann Surg $195: 513-518,1982$

10) Orr J, Shingleton H, Soong $S$ et al: Hemodynamic parameters following pelvic exenteration. Am J Obstet Gynecol 146 : 882-892, 1983

11）高木 弘, 森本用史, 安江满悟ほか：進行直腸癌に 対する骨盤内臓器全摘術後の長期生存例の検討. 癌の臨 $28: 342-344,1982$

12）大見良裕, 江口英雄, 大木繁男洁分：下部直腸癌に 招ける癌先進部から外科的剝離面までの最小距離 之局所再発. 日外会誌 $82: 406-417,1981$

13）小山靖夫, 北條慶一, 森谷冝皓：直腸癌に打ける拡 大郭清の意義一骨盤内臓器全摘術一. 臨外 35 : 1020-1026, 1980

14) Lifshitz S, Johnson R, Roberts JA et al : Intestinal fistula and obstruction following pelvic exenteration. Surg Gynecol Obstet 152 : $630-632,1981$

15）森 武生, 富永 健, 伊藤一二：骨盤内䏩器全摘術 の成績と経験. 臨外 $36: 103-110,1981$ 